\title{
Effect of bevel position on the corneal endothelium after phacoemulsification
}

\author{
Efeito da posição do bisel da caneta de facoemulsificação no endotélio corneano
}

Eduardo Raskin ${ }^{1}$, Jayter Silva Paula ${ }^{1}$, Antonio Augusto Velasco Cruz ${ }^{1}$, Roberto Pinto Coelho ${ }^{1}$

\begin{abstract}
Purpose: To compare the extent of corneal endothelial (CE) cell loss changes in two groups of eyes submitted to phacoemulsification, with the conventional bevel-up tip position in one eye and with the bevel-down tip position in the fellow eye.

Methods: This prospective clinical trial comprised 25 patients with bilateral cataracts subjected to lens removal by phacoemulsification with the conventional bevel-up tip position (Gl) in one eye and with the bevel-down tip position (GII) in the fellow eye. The nuclei were graded clinically on the basis of hardness. The endothelial cell count (ECC) was evaluated preoperatively and 1, 3 and 6 months postoperatively. Total surgical time, effective ultrasound time and complications were also compared between the groups. Statistical analysis was performed by the Tukey Studentized Range test, with repeated measures for the selected periods. For the other parameters a paired t test was used. Data are presented as mean $\pm S D$, with the level of significance set at $p \leq 0.05$.

Results: The mean effective ultrasound time was $8.08 \pm 6.75$ seconds in group I and $7.00 \pm 5.75$ seconds in $\mathrm{Gll}(\mathrm{P}=0.1792)$ and total surgical time was $10.01 \pm 2.46$ minutes in $\mathrm{Gl}$ and $9.86 \pm 2.17$ minutes in $\mathrm{Gll}(\mathrm{p}=0.6267)$, respectively. The paired t test revealed no statistical differences between the groups. Complications were also similar between the groups. Mean endothelial cell count loss was 6.9\% in Gl and 2.8\% in Gll at one month; 6.9\% in Gl and 3.6\% in Gll at three months and $11.9 \%$ in $\mathrm{Gl}$ and $7.6 \%$ in Gll at six months postoperatively. Comparison of endothelial cell count (ECC) showed a statistically significant difference between the groups during the postoperative period.

Conclusion: The conventional bevel-up tip position has a negative effect on corneal endothelial cells compared with the bevel-down position. Since the results of other surgical parameters were similar, the bevel-down tip position should be considered as an option in non-complicated phacoemulsification. Keywords: Cataract extraction; Phacoemulsification/methods; Endothelium, corneal/surgery; Comparative study
\end{abstract}

\section{RESUMO}

Objetivo: Comparamos duas técnicas de cirurgia de catarata. A técnica cirúrgica tradicional, em que direciona a abertura do bisel da ponteira de facoemulsificação para o endotélio corneano, com a técnica oposta, onde a reversão da posição de abertura permite o direcionamento da energia de emulsificação para o núcleo. Estudamos seus efeitos sobre a córnea e possíveis complicações.

Métodos: O trabalho foi divido em quatro tempos: pré-operatório e após 30, 60 e 180 dias. Os pacientes foram divididos em dois grupos: o grupo 1, tratado com a técnica cirúrgica tradicional, com a abertura da ponteira direcionada para o endotélio, e grupo 2, que recebeu tratamento com técnica oposta, direcionada diretamente para o núcleo ou para os fragmentos nucleares. Após as cirurgias, foram estudados: perda endotelial após 30, 60 e 180 dias, tempo total de cirurgia e tempo efetivo de faco.

Resultados: Os resultados intraoperatórios apresentaram o tempo efetivo de facoemulsificação no Gl teve média de 8,08 segundos $(D P=6,75)$ e no Gll, média de 7,0 segundos $(P=0,1792)$ e o tempo total de cirurgia de 10,01 $\pm 2,46$ minutos no Gl e 9,86 $\pm 2,17$ minutos no $G / l(p=0,6267)$ respectivamente. $O$ teste pareado não revelou diferença estatística entre os grupos. As complicações foram similares nos dois grupos. A média de perda de células endoteliais foi de 6,9\% no Gl e 2,8\% in Gll com um mês; $6,9 \%$ no Gl e3,6\% no Gll com três meses e 11,9\% no Gl e 7,6\% no Gll com seis meses de pós-operatório.

Conclusão: Concluímos que a variação da manobra apresentada é segura e pode minimizar perdas no endotélio corneano, podendo ser uma opção na cirurgia da catarata, de acordo com as preferências pessoais do cirurgião.

Descritores: Extração de catarata; Facoemulsificação/métodos; Epitélio posterior/cirurgia; Estudo comparativo

\section{INTRODUCTION}

$S$ ince the introduction of phacoemulsification as a technique to remove cataracts in $1967^{(1)}$, endothelial cell loss has been a major concern of surgeons ${ }^{(2-3)}$. Several intraoperative factors have been implicated in endothelial cell damage such as ultrasound (US) power, heating, irrigating solutions, intraocular lens (IOL) implantation, air bubbles, and inadvertent contact with instruments or nuclear fragments ${ }^{(4-6)}$.

In most phacoemulsification techniques, US energy is directed at the corneal endothelium (CE) due to the bevel-up

\footnotetext{
Work carried out at the Department of Ophthalmology, School of Medicine of Ribeirão Preto, University of São Paulo, Brazil.

Physician, Ophthalmology Departament, School of Medicine of Ribeirão Preto, Universidade de São Paulo (USP), Ribeirão Preto (SP), Brazil.

Correspondence address: Roberto Pinto Coelho. Av. Independência, 2.509 - Ribeirão Preto (SP) - ZIP code: 14025-390 - E-mail: robertopintocoelho@uol.com.br

None of the authors has financial or proprietary interest in any material or method mentioned.

Recebido para publicação em 07.03.2010

Última versão recebida em 14.10.2010

Aprovação em 24.10.2010
}

tip position. The direction of the energy load could be an important reason for cell loss. Theoretically, the down position of the tip would induce less turbulence and better contact between the cataract and the phacoemulsification tip ${ }^{(7-10)}$. Although beveldown techniques have been already described, there is no well long-term controlled study comparing the effect of bevel tip position on the CE and other surgical parameters.

\section{METHODS}

The study was previously approved by the local University Hospital Ethics Committee and written informed consent was obtained from each patient after explanation of the nature of the study.

Twenty-five consecutive patients ranging in age from 42 to 84 years (mean $\pm S D=64.7 \pm 12.5$ years) with fifty bilateral and symmetric senile cataracts were included in this study. According to the lens opacity classification system III (LOCS III) ${ }^{(11)}, 13$ patients had NO3 NC3 and12 patients had NO4 NC4 classification.

Preoperative patient assessment included: best corrected visual acuity (BCVA), biomicroscopy, intraocular pressure (appla- 
nation tonometry), specular microscopy (SM), keratometry, biometry, and fundus examination with a binocular ophthalmoscope. Exclusion criteria were: corneal endothelial count of less than 1500 cells $/ \mathrm{mm}^{2}$, corneal scarring, corneal dystrophy, glaucoma, uveitis, previous intraocular surgery, ocular trauma, and diabetes mellitus.

The position of the bevel tip in the first eye operated upon was randomized for each patient. For the second eye of the same patient the position of the tip was necessarily the opposite one. Thus, two groups of eyes paired according to bevel tip position were obtained for the 25 patients: group 1 (Gl) bevel-up, and group 2 (GII) - bevel-down.

All surgeries were performed by the same surgeon (E.R.) with the phaco chop technique. Briefly, pupils were dilated preoperatively with $1 \%$ tropicamide and $2.5 \%$ phenylephrine hydrochloride peribulbar anesthesia, and BSS Plus was employed as the infusion liquid in all eyes. A temporal $2.75 \mathrm{~mm}$ clear corneal incision was made and dispersive viscoelastic material was inserted. Phacoemulsification with a $0.9 \mathrm{~mm}, 30$ degrees MicroTip (Alcon) was performed with the Legacy $20,000^{\circledR}$ unit (Alcon Laboratories). It starts with the phaco tip positioned with the bevel downward in the central area of the lens, so that it penetrates $2 / 3$ inside when the breaking maneuver is being performed. The Nagahara hook is inserted into the bag opposite to the phaco tip. By rotating the lens, several pieces of nucleus are broken ("chopped") in the whole circumference. In all eyes, a three-piece IOL (AcrySof, Alcon) was implanted in the bag using the Monarch II delivery system. Postoperatively, all patients received the topical combination of tobramycin $3.0 \mathrm{mg} / \mathrm{ml}$-dexamethasone $1.0 \mathrm{mg} / \mathrm{ml}$ (Tobradex ${ }^{\circledR}$ ) q.i.d. for 2 weeks.

The follow-up period was six months. SM was performed again one, three and six months postoperatively. Effective US time, total surgical time and complications were also recorded.

Statistical analysis of changes in endothelial cell count (ECC) between the preoperative and postoperative period was performed by the Tukey Studentized Range test, with repeated measures for the selected periods. For the other parameters a paired t test was used. Data are presented as mean \pm SD, with the level of significance set at $p \leq 0.05$.

\section{RESULTS}

The paired t test revealed no statistical differences between the groups for mean effective US time $(G \mid=8.08 \pm 6.75$ and $G \|=7.00 \pm 5.75$ seconds) ( $p=0.1792)$ or mean total surgical time $(G \mid=10.01 \pm 2.46$ and $G \|=9.86 \pm 2.17$ minutes $)(p=0.6267)$. Complications were also quite similar between the groups (Table 1).

Mean endothelial cell count loss was $6.9 \%$ in $\mathrm{Gl}$ and $2.8 \%$ in Gll at one month; $6.9 \%$ in $\mathrm{Gl}$ and $3.6 \%$ in Gll at three months and $10.8 \%$ in $\mathrm{Gl}$ and $7.6 \%$ in Gll at six months postoperatively. The mean cell loss was $10.8 \%$ in Gl and $7.6 \%$ in Gll (Figure 1). Comparison of ECC by the Tukey Studentized Range test showed statistically significant differences between the groups during the postoperative period (Table 2).

\section{Table 1. Intraoperative and postoperative complications}

\begin{tabular}{lcc}
\hline Complication & Group I & Group II \\
\hline Posterior capsule rupture & 1 & 0 \\
Exacerbated postoperative inflammation & 0 & 1 \\
Transitory macular edema & 1 & 1 \\
Posterior capsule opacification & 6 & 6 \\
\hline
\end{tabular}

\section{DISCUSSION}

A significant decrease in endothelial cell density and increase in corneal thickness during cataract surgery have been reported in several studies ${ }^{(2-6)}$.

Biochemical factors such as reactive oxygen species have been recently implicated in CE cell damage ${ }^{(12)}$.

However, during phacoemulsification mechanical factors related to fragmentation of lens material are unavoidable. Direct mechanical cutting ("jackhammer effect") and implosion of microcavitation bubbles produce extreme although brief instances of heat and pressure ${ }^{(13)}$. The causes of endothelial injury have been related to these mechanical effects of US, as well as to the movements of lens fragments and air bubbles, and high fluid turbulence in the anterior chamber ${ }^{(14-16)}$. All of these factors could directly damage a thin layer of mucinous material on the posterior surface of $\mathrm{CE}^{(17)}$.

To protect the endothelium during cataract surgery, viscoelastic material maintains the anterior chamber depth, cushions the endothelium from the insertion of an IOL and acts as a barrier against the turbulent surgical environment ${ }^{(18-19)}$. Other technologies and techniques have also improved cataract surgery, with reduction of the US energy produced(20-23).

The few authors who have described variations in the position of the phacoemulsification tip ${ }^{(7-9)}$ have suggested that bevel facing down would cause less turbulence of lens fragments and a better contact between cataract tissue and the phaco tip. In addition, this technique variation could prevent CE damage, improving the efficacy of the procedure. Although these studies showed significant differences regarding endothelial cell loss, the effect of bevel position as an isolated factor was not consistently studied. Changes in both bevel position and in other surgical details were used and their effects on CE may have been attributable to any of these factors ${ }^{(7-9)}$.

In order to study the effects of bevel position and of US waves on CE, an artificial model was employed ${ }^{(10)}$. Nevertheless, no differences were detected according to bevel position and the experimental situation was completely different from a real surgery.

The present study involved a randomized paired eye and showed a significantly greater ECC loss in phacoemulsification with the conventional bevel-up tip position when compared

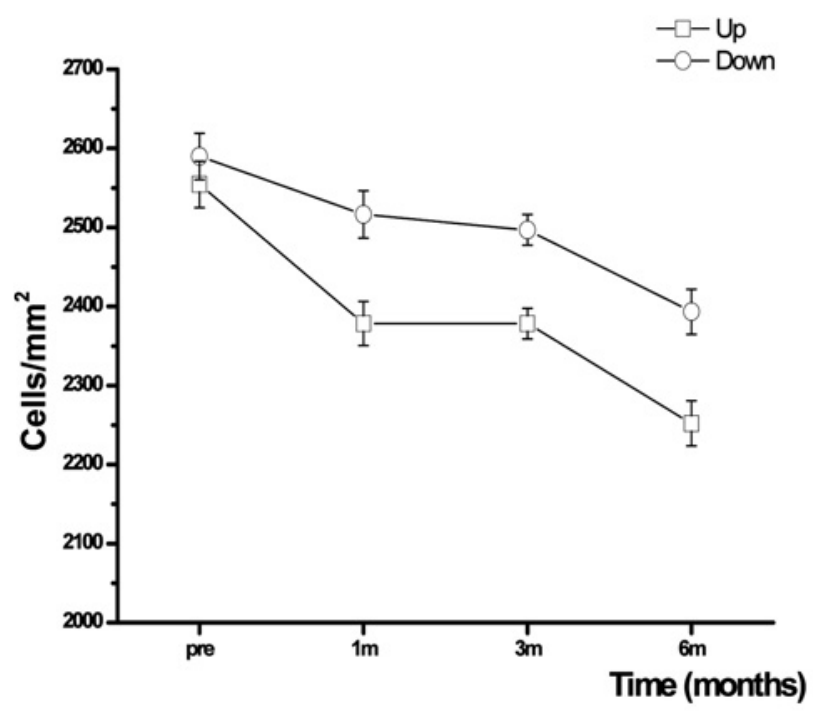

Figure 1. Mean endothelial cell count for Gl (bevel-up tip position) and GII (beveldown tip position) patients with time. 
Table 2. Comparison of endothelial cell count (mean \pm SD) at all time points studied

\begin{tabular}{lcr}
\hline Period & $\begin{array}{c}\text { Group I } \\
\text { Bevel-up }\end{array}$ & $\begin{array}{c}\text { Group II } \\
\text { Bevel-down }\end{array}$ \\
\hline Preoperative & $2554.5 \pm 385.6$ & $2589.8 \pm 385.3$ \\
1 month postoperatively & $2378.4 \pm 461.4$ & $2516.5 \pm 421.1$ \\
3 months postoperatively & $2378.4 \pm 351.0$ & $2496.9 \pm 413.0$ \\
6 months postoperatively & $2252.0 \pm 310.7$ & $2393.2 \pm 321.5$ \\
\hline
\end{tabular}

with the bevel-down tip position. Moreover, we believe that the bevel-down position is an easier technique which can facilitate the attachment of the lens fragments.

The safety of this approach could be an important concern. A posterior direction of the US wave could rupture the posterior capsule and dislocate pieces of the nucleus to the vitreous cavity. On the other hand, with this technique, the epinucleus could act as a barrier, preventing these complications in both techniques. Our study supported this hypothesis since no differences in complications were observed between these two approaches.

As other surgical parameters showed similar findings, we concluded that both techniques may be used, according to the surgeon preference. As bevel-down tip position had fewer negative effects on the corneal endothelium, it should be considered as a safe option in non-complicated phacoemulsification.

\section{REFERENCES}

1. Kelman CD. Phaco-emulsification and aspiration. A new technique of cataract removal: a preliminary report. Am J Ophthalmol. 1967;64(1):23-35

2. Dick HB, Kohnen T, Jacobi FK, Jacobi KW. Long-term endothelial cell loss following phacoemulsification through a temporal clear corneal incision. J Cataract Refract Surg. 1996;22(1):63-71

3. Kosrirukvongs P, Slade SG, Berkeley RG. Corneal endothelial changes after divide and conquer versus chip and flip phacoemulsification. J Cataract Refract Surg. 1997;23(7):1006-12. Comment in: J Cataract Refract Surg. 1997;23(7):967-8.

4. Krey HF. Ultrasonic turbulences at the phacoemulsification tip. J Cataract Refract Surg. 1989;15(3):343-4.

5. Saito K, Miyake K, McNeil PL, Kato K, Yago K, Sugai N. Plasma membrane disruption underlies injury of the corneal endothelium by ultrasound. Exp Eye Res. 1999; $68(4) 431-7$

6. Beesley RD, Olson RJ, Brady SE. The effects of prolonged phacoemulsification time on the corneal endothelium. Ann Ophthalmol. 1986;18(6):216-9;222
7. Kohlhaas M, Klemm M, Kammann J, Richard G. Endothelial cell loss secondary to two different phacoemulsification techniques. Ophthalmic Surg Lasers. 1998; 29(11):890-5.

8. Joo C-K, Kim YH. Phacoemulsification with a bevel-down phaco tip: phaco-drill. J Cataract Refract Surg. 1997;23(8):1149-52. Comment in: J Cataract Refract Surg 1998;24(2):147.

9. Gregg FM. Bevel-down phaco. J Cataract Refract Surg. 1998; 24(2)(:147. Comment on: J Cataract Refract Surg. 1997;23(8):1149-52.

10. Frohn A, Dick HB, Fritzen CP. Corneal impact of ultrasound and bevel position in phacoemulsification.J Cataract Refract Surg. 2002;28(9):1667-70.

11. Chylack LT Jr, Wolfe JK, Singer DM, Leske MC, Bullimore MA, Bailey IL, et al. The Lens Opacities Classification System III. The Longitudinal Study of Cataract Study Group. Arch Ophthalmol. 1993;111(6):831-6.

12. Hull DS. Oxygen free radical and corneal endothelium. Trans Am Ophthalmol Soc.1990;88:463-511.

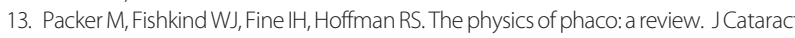
Refract Surg. 2005; 31(2):424-31.

14. Hayashi K, Hayashi H, Nakao F, Hayashi F. Risk factors for corneal endothelial injury during phacoemulsification. J Cataract Refract Surg. 1996;22(8):1079-84.

15. Eiferman RA, Wilkins EL. The effect of air on human corneal endothelium. Am J Ophthalmol. 1981;92(3):328-31

16. Leibowitz HM, Laing RA, Sandstrom M. Corneal endothelium; the effect of air in the anterior chamber. Arch Ophthalmol. 1974;92(3):227-30.

17. Kim EK, Cristol SM, Kim HL, Kang SJ, Park JW, Edelhauser HF. et al. The mucinous laye of corneal endothelial cells. Yonsei Med J. 2000;41(5):651-6.

18. Ravalico G, Tognetto D, Baccara F, Lovisato A. Corneal endothelial protection by different viscoelastics during phacoemulsification. J Cataract Refract Surg. 1997; 23(3):433-9.

19. Liesegang TJ. Viscoelastic substances in ophthalmology. Surv Ophthalmol. 1990; 34(4):268-93


phacoemulsification using the Staar Sonic Wave system. .J Cataract Refract Surg. 2002;28(9):1581-4.

21. Davison JA. Ultrasonic power reduction during phacoemulsification using ad junctive NeoSoniX technology. J J Cataract Refract Surg 2005;31(5):1015-9.

22. Badoza D, Fernandez Mendy J, Ganly M. Phacoemulsification using the burst mode. J Cataract Refract Surg. 2003;29(6):1101-5

23. McNeill I. Flared phacoemulsification tips to decrease ultrasound time and energy in cataract surgery. J Cataract Refract Surg. 2001;27(9):1433-6.

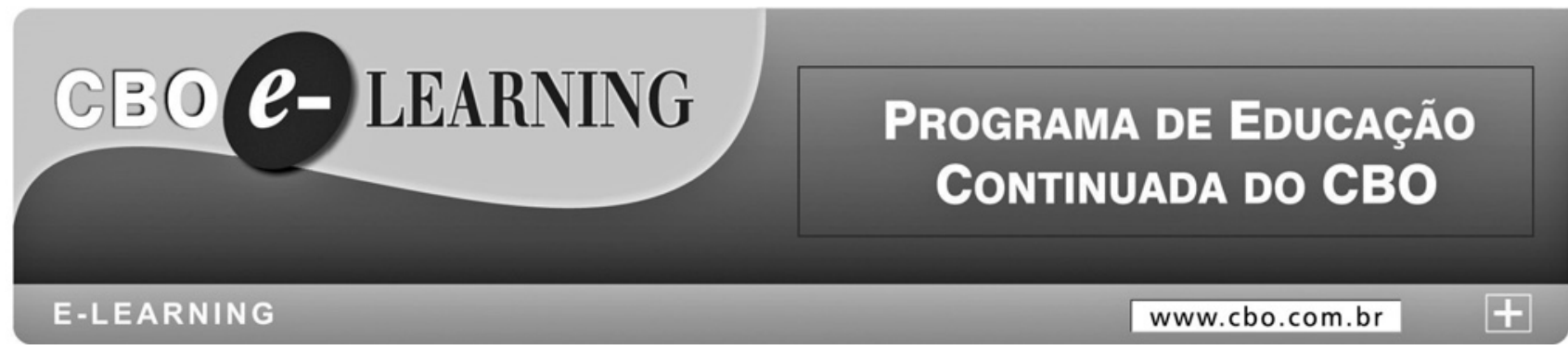

